\title{
Morphometric variations of Asian Common Palm Civet (Paradoxurus hermaphroditus, Pallas 1777) from Bali Island, Indonesia as the basis of morphometrics diversity data
}

\author{
ARIS WINAYA ${ }^{1,2, \vartheta}$, MAFTUCHAH ${ }^{2, \vartheta}$, CARLA MOROS NICOLÁS ${ }^{3}$, DWI PRASETYO $^{1}$ \\ ${ }^{1}$ Department of Animal Science, Faculty of Agriculture and Animal Science, Universitas Muhammadiyah Malang. Jl. Raya Tlogomas 246, Malang \\ 65119, East Java, Indonesia. Tel.: +62-341-464318, Fax.: +62-341-460435, `email: winaya @ umm.ac.id \\ ${ }^{2}$ Center for Biotechnology Development, Universitas Muhammadiyah Malang. Jl. Raya Tlogomas 246, Malang 65119, East Java, Indonesia. \\ Tel.: +62-341-464318, "email: maftuchah@umm.ac.id \\ ${ }^{3}$ Department of Cell Biology, School of Medicine, University of Murcia. 30100 Campus de Espinardo, Murcia, Spain
}

Manuscript received: 8 December 2019. Revision accepted: 13 February 2020.

\begin{abstract}
Winaya A, Maftuchah, Nicolas CM, Prasetyo D. 2020. Morphometric variations of Asian Common Palm Civet (Paradoxurus Hermaphroditus, Pallas 1777) from Bali Island, Indonesia as the basis of morphometrics diversity data. Biodiversitas 21: 1027-1034. Asian Common Palm Civet (Paradoxurus hermaphroditus, Pallas 1777) is one of the small carnivores that also lives in Bali island, Indonesia. Civets can process coffee beans by fermenting them in the digestive tract, so the coffee beans have a unique aroma. This coffee product, commonly known as Kopi Luwak, is the most expensive type of coffee in the world. The purposes of this study were to obtain the morphometric variations, genetic diversity, and genetic relationship of Bali civets. In this study, we involved 73 civets from four different areas (Bangli, Tabanan, Gianyar, and Denpasar) of Bali Islands, Indonesia. The quantitative character was the body size of animals, and the qualitative character was their hair color. The body size among populations was not significantly different (P>0.05). The complete canonical structure analysis showed that tail length (1.04) and body length (0.76) in canonical 1 and body height (0.96) and head width (0.94) in canonical 2 could be used as a group differentiator. The genetic distance among Bali civets was categorized as close except Bangli civets having far distance than others.
\end{abstract}

Keywords: Bali, canonical, civet, diversity, genetic, morphometry

\section{INTRODUCTION}

Asian Common Palm Civet (Paradoxurus hermaphroditus, Pallas 1777) is generally renowned as Luwak by most Indonesians. This animal is famous due to its coffee production, which is expanded industrially by coffee companies. This is commonly called Kopi Luwak, which is the most expensive coffee in Indonesia even in the world. The fermentation processes taking place in the digestive tract of civet presumably produce a unique aroma and a good taste of the coffee and that uniqueness is preferred by local and foreign coffee consumers.

As a consequence, the civets are exploited massively by hunting or nurturing these animals for producing Luwak coffee. Therefore, it is crucial to study civets extensively to protect or conserve them. However, the study of Indonesia civet is still limited; therefore, it is crucial to determine the appropriate strategies to protect the animals and avoid extinction. Even though civets are considered as a pest rather than conserved animals, but civets crucially act as a buffer of ecosystem regarding their contribution to seeds dispersers (Jothish 2011).

The International Union for Conservation of Nature (IUCN) includes the Asian palm civet animals on the least concern list, which means the species have the least attention since the population was considered numerous; therefore, they are far from extinction (Duckworth et al. 2016). In Indonesia, a civet does not belong to a protected species. However, its trade (domestic and international) is regulated through a quota set annually by the Indonesian Institute of Sciences. In the last five years, quotas of 250300 individuals were allocated to the provinces of North Sumatra, Lampung, West Java, Central Java, and West Lesser Sunda Islands (Wirdateti unpublished data in Nijman et al. 2014). Civet is a nocturnal animal, and people pay less attention to this mammal until recently (Eaton et al. 2010). Research on civets in Indonesia is still insufficiently conducted, especially on the morphometry characters and their habitats. The study on civets that have been reported in Indonesia mostly around organs of civet that is: (i) Gastrointestinal organs, the anatomy of histology of the tongue (Kosim 2015); and intestinal morphology (Rizkiantino 2015); (ii) Civet reproduction, including female and male reproductive organs (Apriliani 2012; Putra 2012); (iii) Civet habitats, such as breeding and activity management (Nur 2013) and welfare management as a studying animal (Laela 2013). Based on those previous studies, it could be said that research leading to the determination of the genetic status of Bali civet was underrepresented.

The aim of the study was to determine the morphometric variation, genetic diversity, and genetic relationship among Bali civets. The information of this study is expected to be a useful reference for germplasm conservation and the genetic materials as well. Furthermore, it can be applied as a source of genetic diversity status on Bali civets. 


\section{MATERIALS AND METHODS}

\section{Study area}

The areas of study covered four parts of Bali island (Bali Province, Indonesia), including Denpasar City, Bangli, Gianyar, and Tabanan Districts. This province is situated at the coordinates of $08^{\circ} 3^{\prime} 40^{\prime \prime}$ to $08^{\circ} 50^{\prime} 48^{\prime \prime} \mathrm{S}$ and $114^{\circ} 25^{\prime} 53^{\prime \prime}$ to $115^{\circ} 42^{\prime} 40^{\prime \prime} \mathrm{E}$, which makes this area is tropical like other regions in Indonesia. The total area of Bali Province reaches $5,636.66 \mathrm{~km}^{2}$ or $0.29 \%$ of the total area of the Indonesian Archipelago.

The land contour of Bali Island consists of flat land 122.65 ha $(0 \%$ to $2 \%)$, undulating land 118.34 ha ( $2 \%$ to $15 \%)$, steep land 190.49 ha (15\% to $40 \%)$, and very steep land 132.19 ha (> 40\%). The Bali region, in general, has a tropical sea climate that is influenced by seasonal winds. There are dry and rainy seasons interspersed with transition seasons. The highest average temperature in the Bali region is in Buleleng District, reaching $28.7^{\circ} \mathrm{C}$ with an average humidity of $75 \%$. The lowest average air temperature occurs in Tabanan District that reaches $20.6^{\circ} \mathrm{C}$ with the highest average humidity level of $86 \%$.

\section{Materials}

This study involved 73 Bali civets nurtured and captured from the forest by farmers. The primary data were recorded on the spot of the sampling location (Figure 1). The main tools of this study were measuring tape and ruler, calipers, digital camera, hygrometer, thermometer, and GPS devices.

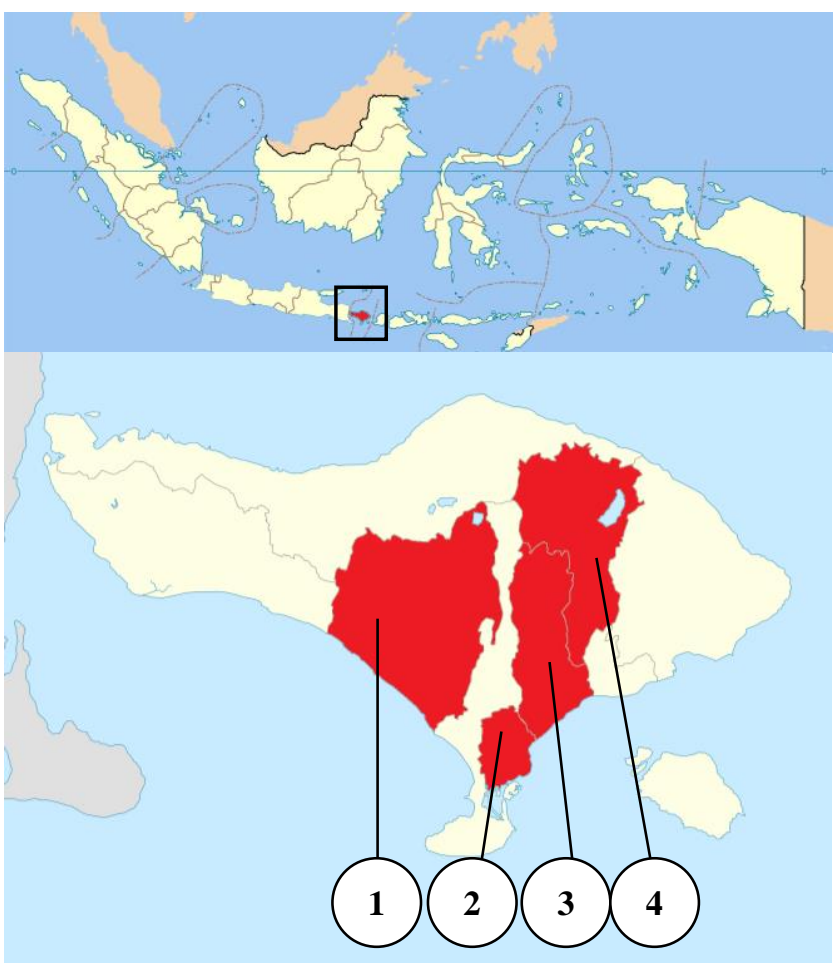

Figure 1. The map of research locations in Bali Island, Indonesia, i.e. 1. Tabanan, 2. Denpasar, 3. Bangli, 4. Gianyar. The box and colored areas indicate places of animal sampling
The observed variables consisted of two variables, namely qualitative and quantitative. The quantitative variable was morphometric characters of civet. The variables were determined by the approaching of Cuscus (Phalangeridae fam.) animal (Widayati 2003). We used a cuscus animal as a model for approaching the morphometric measurement because the researcher found no standard for civet morphometric measurement up to now. In contrast, the qualitative variable of civet was hair color, which can be visually analyzed.

\section{Data analysis}

Relative frequency and descriptive analysis

The morphometric measurement of civet was analyzed using descriptive analysis. It was conducted to hopefully obtain the variation of morphometric characters of civet. The analysis of data applied mean values, standard deviation, and the coefficient of variations of each variant in the civet by (Steel and Torrie 1995).

\section{Nested analysis}

The nested analysis was applied to determine the differences among Bali civets. The morphometric characters based on the sampling area of Bali civet was applied. The mathematical model of nested design as follows:

$$
\mathrm{Y}_{i j k}=\mu+\alpha_{i}+\beta\left({ }_{i}\right)_{j}+\sum_{i j}
$$

Where:

$\mathrm{Y}_{\mathrm{ijk}}$ : observed of factor A at level- $-_{\mathrm{i}}$, factor B at level- $\mathrm{-}_{\mathrm{j}}$,

$\mu \quad$ : factor $\mathrm{C}$ at level ${ }_{-\mathrm{k}}$, and factor $\mathrm{D}$ at level ${ }_{-\mathrm{l}}$.

$\alpha_{\mathrm{i}} \quad$ : mean value;

$\beta\left({ }_{i}\right)_{j}$ : effect of group $-\mathrm{i}$;

$\sum_{\mathrm{ij}}$ : effect of subgroup $_{-j}$ in group ${ }_{-i}$ sub of the subgroup (error)

\section{Discriminant and canonical correlation analysis}

Discriminant analysis was implemented to determine the genetic distance (Zhao and Maclean 2000) and the discriminant function using the Mahalanobis distance by the minimum quadratic square distance in which the measurement based on (Nei 1987) formula as follows:

$$
D_{(i, j)}^{2}=\left(\bar{X}_{i}-\bar{X}_{j}\right) C^{-1}\left(\bar{X}_{i}-\bar{X}_{j}\right)
$$

Where:

$\mathrm{D}^{2}(i, j)$ : Mahalanobis value as a measure of the genetic square distance between the $i$ of civet group and the $j$ of civet group

$C^{-1} \quad$ : the inverse of the covariance matrix of mixed variance between variables

$X_{i} \quad$ : the vector of mean values of observation from the $i$ civet in each quantitative variable

$X_{j} \quad$ : the vector of mean values of observation from the $j$ civet in each quantitative variable 


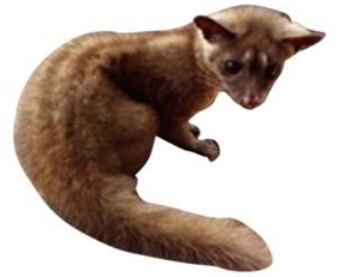

A

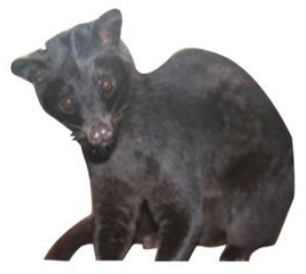

B

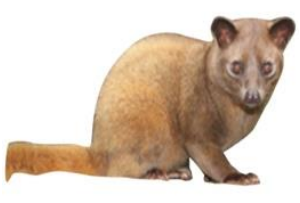

C

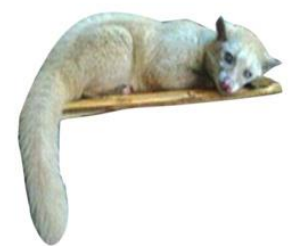

D

Figure 2. Bali civet hair color: A. Grayish-Brown; B. Black; C. Brownish-Yellow; and D. White

The calculation of Mahalanobis distance was performed using SPSS software version 21 with Proc Discriminant analysis. The canonical analysis was used to know the canonical description of the civet group, similarity, and mixture values within and among civets (Herera et al. 1996). This analysis was also used to determine some variables of the morphometry measurements that have a close relationship with the population of civet (subspecies or species differentiator).

\section{RESULTS AND DISCUSSIONS}

\section{Bali civet and climatic conditions}

Civet or Luwak animals also dwell on Bali island as the environmental conditions of Bali are not entirely different from other regions on the mainland of Asia continents. Additionally, in some locations of Bali Island is very suitable for coffee plants, so civets reside there because they can easily find a source of food from these coffee plantations. At the same time, coffee farmers benefit from their existence through civet coffee or Kopi Luwak production (Bale 2019).

Furthermore, Bali's faunas are categorized as tropical rainforests animals, like bird species, reptiles, and mammals. However, in the last few decades, the rainforest ecosystem has undergone an imbalance condition due to illegal logging and climate change. So, a significant number of trees and endemic animals have slowly declined even worse some of them are extinct. Civets belonging to rainforest animals also have an essential role in plant regeneration by seed dispersal (Mudappa et al. 2010; Nakashima et al. 2013).

As Su and Sale (2007) stated that civet is one of forest rehabilitation agents, especially on dispersing seeds of plants in the forest or plantation because civets only eat ripe fruits. Civets are a carnivorous nocturnal animal consuming the major ripe fruits like banana and papaya, coffee, and palm. Sometimes this species also eats small vertebrates, reptiles, and insects (Mudappa et al. 2010). Therefore, they are also named frugivorous animals (Nakashima et al. 2013; Nakabayashi et al. 2016). The digestive system of civet is quite simple. It only processes the peel and flesh of the fruit while the seeds remain with the feces, including coffee beans. The hard grains are removed from the fermented digestion of civet. That is the reason why civets only eat the best and most excellent coffee. Regarding the plants' regeneration in the forest, its process occurs when the feces of civets are scattered in different places where they ever defecate. It is clear how impactful civets are for the forest ecology (Nakashima and Sukor 2010).

\section{Qualitative characters of Bali civet}

The qualitative character observed in this study was civets' hair color. Through hair color inquiry, it could be found the color variation of Bali civet. The investigation found four types of hair color from Bali civets, like Grayish-Brown, Brownish-Yellow, Black, and White, from 73 animal samples (Figure 2). According to (Wright and Walters 1981), all of the alleles encoding hair color variations are located on the autosomal chromosome and sex chromosome of $\mathrm{X}$. While the black color encoded by $B$ gene is located at the $B \sim b$ locus, and mutations in this gene will express brown and light brown.

The phenotypic character of hair color in the animal is an expression of many or several pairs of the gene. The black and brown color variations in Bali civets are presumably determined by the $B$ gene appearing in a recessive homozygote $(b b)$ gene and it is epistasis of the $A$ gene expressed by recessive homozygote $(a a)$. It blocks the expression of other genes in heterozygous conditions. The grayish-brown color of the Bali civet is assumed also regulated by the $B$ gene which expression is the mutation of the $B$ gene.

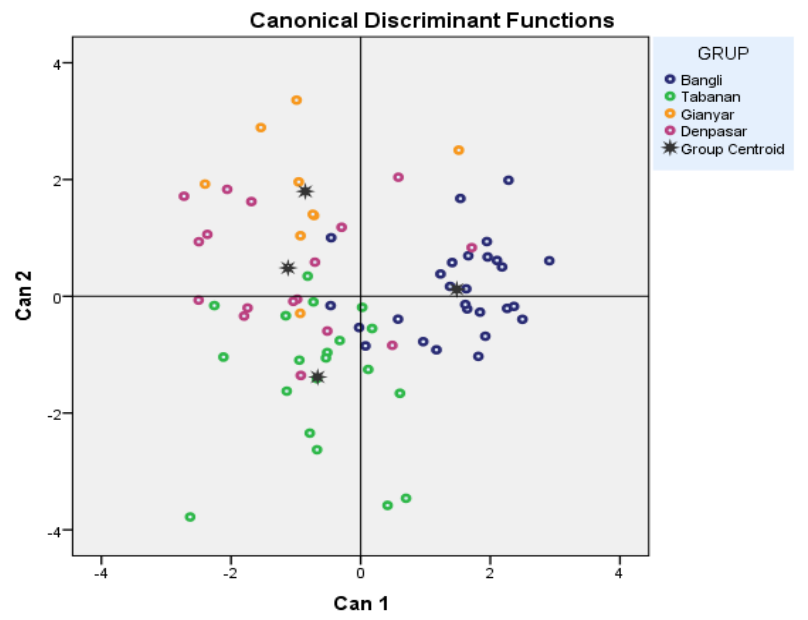

Figure 3. the distribution of Bali civet population according to morphometric measurement variation based on canonical discriminant function 
Table 1. The hair color of Bali civets

\begin{tabular}{|c|c|c|c|c|c|}
\hline \multirow{2}{*}{ Hair color } & \multicolumn{4}{|c|}{ Sampling area } & \multirow{2}{*}{ Total cumulative } \\
\hline & Bangli & Tabanan & Gianyar & Denpasar & \\
\hline Sampling number (head) & $(27)$ & $(20)$ & (9) & $(17)$ & $(73)$ \\
\hline Grayish-brown (\%) & 33.33 & 45.00 & 44.44 & 29.41 & 38.05 \\
\hline Black (\%) & 51.85 & 45.00 & 22.22 & 23.53 & 35.65 \\
\hline Brownish-yellow (\%) & 14.81 & 5.00 & 22.22 & 47.00 & 22.27 \\
\hline White (\%) & 0.00 & 5.00 & 11.11 & 0.00 & 4.03 \\
\hline
\end{tabular}

Whereas, the brownish-yellow color of the Bali civets is presumably regulated by the $C$ gene at locus $C$ where it is expressed in the $c c$ recessive homozygote, which is epistasis to other genes expressed in the heterozygous conditions. Castle (1954) stated that $C$ locus consists of $C C, C c$, and $c c$. The $C$ allele in the homozygous dominant and heterozygous conditions controlled the expression of the color. In a recessive condition, the $c c$ allele will affect albinism. The turn on or off of the $C$ gene will cause the black and yellow pigments of the hair.

The white color is managed by the $C$ gene in locus $C$ resulting in the basic color to not take place. According to (Suwed and Napitupulu 2011), the $C$ gene prevents color expression in a different form. The genes in $C$ locus typically control the expression of full color, but if any recessive gene in locus $C$, it will affect the color not to develop or albinism. The most frequent hair color in Bali civets was grayish-brown $(38.05 \%)$, while white color was the lowest $(4.03 \%)$ (Table 1$)$. This study corresponded to (Wilson and Reeder 2005) that Asian common palm civets generally have brownish-gray hair color, and some at both sides of the body have a line of black spots.

The hair color of the animal is one crucial factor in the traits of species or breeds. Also, hair color could be a marker for the particular species of animal. Asian Common Palm Civet (Paradoxurus Hermaphroditus) also has variations in hair color at various places with different climatic conditions, especially in the Asian continent (Pocock 1939). Phenotypic ally, common Palm Civet, has dark spots coalesce into stripes on the sides. It has three longitudinal stripes on its back. The muzzle, ears, lower legs, and distal half of the tail are black (Dev Choudhury 2015). The typical color of the hair of the Asian Common Palm Civet is brownish-gray to grayish-black with grayishwhite lines along the body, and Sharma (2004) found the albino event of civet in Rajasthan, India.

\section{Morphometric characters of Bali civet}

Because genetic differences often produce morphological variations so that morphological differences can be used as an indicator of possible underlying genetic differences (Fabriciusová et al. 2008). Morphometric is simply a quantitative way to shape comparisons among animals, and shape analysis plays an essential role in many kinds of biological studies. The variation in biological processes produces differences in shape between individuals or their parts, such as disease or injury, ontogenetic development, adaptation to local geographic factors, or longterm evolutionary diversification. Hence, shape analysis is one approach to understanding the diverse causes of variation and morphological transformation (Zelditch et al. 2004).

Body size is a typical quantitative or complex trait that shows a continuous variation (Kemper et al. 2012). Previous studies have reported that many discrete genes are involved in individual development, genetic diseases, or body size regulation. It has been reported that some genes involved in promoting growth or mutations in genes could cause tall stature (e.g., gigantism) and overgrowth (Sun et al. 2019). Body size is a significant factor influencing animal morphology, physiology, ecology, evolution, and extinction probability (Cardillo et al. 2005; Meiri et al. 2009).

The categorized morphometry variables can support the quantitative trait data that can combine with molecular data for genetic variation in animals or livestock (Patou et al. 2010; Pissard et al. 2008; Warwick et al. 1995). The Bali civet from Bangli district has the lowest variation on morphometry measurement compared to the other populations $(7.66 \%$ to $33.75 \%)$. In contrast, the highest variation was found in the Tabanan district $(16.02 \%$ to 74.74\%) (Table 2).

The variation of morphometry measurements could be due to the different places and environmental conditions, like the availability of food. According to Ilham (2012), the variation of body weight in an animal is commonly caused by different environmental conditions, including kinds and amount of food consumption. Concerning Bali civets, the variation on body length, chest circumference, and chest width represents the Bali civet weight diversity.

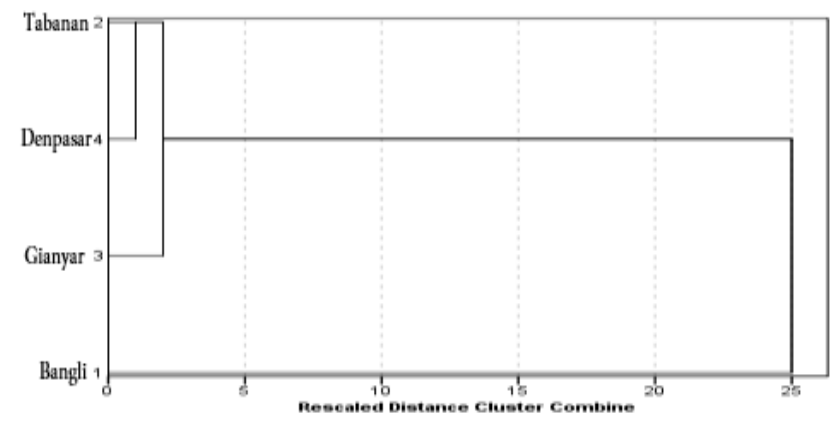

Figure 4. The dendrogram of Bali civet among populations 
Table 2. The body measurement of Bali civet

\begin{tabular}{|c|c|c|c|c|}
\hline \multirow[b]{2}{*}{ Body measurements } & \multicolumn{4}{|c|}{ Districts } \\
\hline & $\begin{array}{c}\text { Bangli } \pm \text { SD } \\
\text { (\% CV) }\end{array}$ & $\begin{array}{c}\text { Tabanan } \pm \text { SD } \\
(\% \text { CV })\end{array}$ & $\begin{array}{c}\text { Gianyar } \pm \text { SD } \\
(\% \mathrm{CV})\end{array}$ & $\begin{array}{c}\text { Denpasar } \pm \text { SD } \\
(\% \mathrm{CV})\end{array}$ \\
\hline Sample number (head) & $(27)$ & $(20)$ & (9) & $(17)$ \\
\hline Bodyweight (kg) & $\begin{array}{c}2.17 \pm 0.73 \\
(33.75)\end{array}$ & $\begin{array}{c}2.78 \pm 2.07 \\
(74.74)\end{array}$ & $\begin{array}{c}2.38 \pm 1.07 \\
(45.02)\end{array}$ & $\begin{array}{c}2.93 \pm 2.06 \\
(70.22)\end{array}$ \\
\hline Total body length $(\mathrm{cm})$ & $\begin{array}{c}50.04 \pm 6.33 \\
(12.66)\end{array}$ & $\begin{array}{c}45.70 \pm 9.87 \\
(21.59)\end{array}$ & $\begin{array}{c}43.88 \pm 8.94 \\
(20.36)\end{array}$ & $\begin{array}{c}41.35 \pm 11.82 \\
(28.59)\end{array}$ \\
\hline Body length $(\mathrm{cm})$ & $\begin{array}{c}32.26 \pm 3.46 \\
\quad(10.72)\end{array}$ & $\begin{array}{c}31.40 \pm 7.38 \\
\quad(23.50)\end{array}$ & $\begin{array}{c}30.88 \pm 5.84 \\
(18.91)\end{array}$ & $\begin{array}{c}29.94 \pm 9.24 \\
(30.85)\end{array}$ \\
\hline Body height $(\mathrm{cm})$ & $\begin{array}{c}18.37 \pm 3.26 \\
(17.75)\end{array}$ & $\begin{array}{c}16.35 \pm 4.31 \\
(26.35)\end{array}$ & $\begin{array}{c}16.55 \pm 4.33 \\
(26.17)\end{array}$ & $\begin{array}{c}15.58 \pm 4.86 \\
(31.19)\end{array}$ \\
\hline Head length $(\mathrm{cm})$ & $\begin{array}{c}9.55 \pm 1.31 \\
(13.72)\end{array}$ & $\begin{array}{c}9.65 \pm 1.95 \\
(20.25)\end{array}$ & $\begin{array}{c}10.77 \pm 1.86 \\
(17.22)\end{array}$ & $\begin{array}{l}9.15 \pm 1.98 \\
(21.67)\end{array}$ \\
\hline Head width $(\mathrm{cm})$ & $\begin{array}{c}6.47 \pm 1.01 \\
(15.61)\end{array}$ & $\begin{array}{c}6.25 \pm 1.92 \\
(30.66)\end{array}$ & $\begin{array}{c}8.00 \pm 1.41 \\
(17.68)\end{array}$ & $\begin{array}{c}6.62 \pm 1.75 \\
(26.38)\end{array}$ \\
\hline Chest girth $(\mathrm{cm})$ & $\begin{array}{l}23.82 \pm 4.46 \\
\quad(18.74)\end{array}$ & $\begin{array}{c}28.80 \pm 11.61 \\
\quad(40.30)\end{array}$ & $\begin{array}{c}25.44 \pm 6.46 \\
\quad(25.40)\end{array}$ & $\begin{array}{c}26.12 \pm 9.31 \\
\quad(35.63)\end{array}$ \\
\hline Chest width $(\mathrm{cm})$ & $\begin{array}{c}10.44 \pm 1.63 \\
(15.56)\end{array}$ & $\begin{array}{c}10.85 \pm 4.26 \\
(39.25)\end{array}$ & $\begin{array}{c}12.22 \pm 2.86 \\
(23.42)\end{array}$ & $\begin{array}{c}10.53 \pm 3.99 \\
(37.86)\end{array}$ \\
\hline Front leg length $(\mathrm{cm})$ & $\begin{array}{c}10.41 \pm 0.80 \\
(7.66)\end{array}$ & $\begin{array}{c}9.90 \pm 1.59 \\
(16.02)\end{array}$ & $\begin{array}{c}9.77 \pm 1.56 \\
(15.99)\end{array}$ & $\begin{array}{c}9.53 \pm 2.24 \\
(23.50)\end{array}$ \\
\hline Hind leg length $(\mathrm{cm})$ & $\begin{array}{c}6.92 \pm 0.81 \\
(11.62)\end{array}$ & $\begin{array}{c}6.55 \pm 1.47 \\
(22.41)\end{array}$ & $\begin{array}{c}7.67 \pm 1.00 \\
(13.04)\end{array}$ & $\begin{array}{c}6.71 \pm 1.69 \\
(25,16)\end{array}$ \\
\hline Tail length $(\mathrm{cm})$ & $\begin{array}{c}43.11 \pm 4,53 \\
(10,52)\end{array}$ & $\begin{array}{c}36.35 \pm 6.20 \\
(17.06)\end{array}$ & $\begin{array}{c}37.22 \pm 6.20 \\
(16.66)\end{array}$ & $\begin{array}{c}37.29 \pm 10.32 \\
(27.67)\end{array}$ \\
\hline Tail base circumference $(\mathrm{cm})$ & $\begin{array}{c}8,37 \pm 0,03 \\
\quad(11,06)\end{array}$ & $\begin{array}{c}8.35 \pm 3.18 \\
(38.12)\end{array}$ & $\begin{array}{l}9.33 \pm 2.45 \\
(26.24)\end{array}$ & $\begin{array}{c}9.58 \pm 3.45 \\
(35.95)\end{array}$ \\
\hline Tail end circumference $(\mathrm{cm})$ & $\begin{array}{c}4,07 \pm 0,73 \\
(17,92)\end{array}$ & $\begin{array}{c}3.67 \pm 0.86 \\
(23.47)\end{array}$ & $\begin{array}{c}4.22 \pm 0.97 \\
\quad(23.02)\end{array}$ & $\begin{array}{c}3.77 \pm 1.30 \\
(34.54)\end{array}$ \\
\hline
\end{tabular}

Notes: $\mathrm{CV}$ : coefficient of variance

The common palm civet (Paradoxurus hermaphroditus) is a small carnivore ( 2 to $5 \mathrm{~kg}$ on weight) that is widely spread in South and Southeast Asia (Wozencraft 2005; Jennings and Veron 2009), and (Patou et al. 2010) for current taxonomic status. While the average adult civet weight was around $3 \mathrm{~kg}$ (Patou et al. 2010; Pai 2008). It corresponded to this study that Bali civets have bodyweight around $3.30 \mathrm{~kg}$ and $3.78 \mathrm{~kg}$ on two to three years old and more than three years old, respectively. While the rate of total body length of Bali civets at one year old or above was ranging from 50.46 to $54.66 \mathrm{~cm}$. This result confirmed (Duckworth et al. 2016) study that Asian palm civet has total body length ranging from 42 to $71 \mathrm{~cm}$. Pai's (2008) study also indicated that the total body length of Asian palm civet was around $53 \mathrm{~cm}$.

\section{The genetic variation of Bali civet}

According to morphometric measurements in Bali civet, we found some genetic variations in Bali civets based on population similarity, canonical, and genetic distance analysis. The similarity analysis displayed that the highest degree of similarity was found in Gianyar District (88.90\%), followed by Bangli District $(85.20 \%)$, Tabanan District $(75.00 \%)$, and the Denpasar City, which is the lowest one, $(58.80 \%)$ (Table 3$)$.
Bali civet population has a high value on similarity. It can be assumed that the mixture of genes coming from the outside population was low. This is consistent, too (Dossa et al. 2007) that the phenotypic similarity can obtain a genetic identity. However, there are some constraints regarding the use of the phenotypic character for genetic identities due to the different alleles or genes in the different locus. In some instances, it is suspected that differences in power expression or degrees of the genes expression level depend on the individual or species.

The canonical analysis can determine the morphometric measurements having the most significant discriminator for Bali civets. In canonical 1 , the findings were tail length (1.04) and body length (0.76), and in canonical 2, it was found body height (0.96) and head width (0.94) (Table 4). Thus, the measurement of tail length, body length, body weight, and head width can be used as a predictor to differ Bali civet population-based on morphometric characters.

On the other hand, it shows that the variable of body weight, front and hind leg length, and chest circumference cannot be used as a differentiator variable of Bali civet population. The analysis of total canonical structure showed that those variables have negative values on canonical 1 and 2 . The lower value obtained from the complete analysis of canonical structures cannot be used as a distinguished variable for a population in general. 
Table 3. The similarity of morphometry measurement of Bali civet

\begin{tabular}{|c|c|c|c|c|c|c|}
\hline \multirow{2}{*}{ Sampling area } & & \multicolumn{3}{|c|}{ Sampling area } & \multirow[b]{2}{*}{ Denpasar } & \multirow{2}{*}{ Total } \\
\hline & & Bangli & Tabanan & Gianyar & & \\
\hline \multirow{2}{*}{ Bangli } & $\mathrm{N}$ & 23 & 3 & 1 & 0 & 27 \\
\hline & $(\%)$ & 85.20 & 11.70 & 3.70 & 0.00 & 100 \\
\hline \multirow[t]{2}{*}{ Tabanan } & $\mathrm{N}$ & 1 & 15 & 1 & 3 & 20 \\
\hline & $(\%)$ & 5.00 & 75.00 & 5.00 & 15.00 & 100 \\
\hline \multirow[t]{2}{*}{ Gianyar } & $\mathrm{N}$ & 0 & 1 & 8 & 0 & 9 \\
\hline & $(\%)$ & 0.0 & 11.10 & 88.90 & 0.00 & 100 \\
\hline \multirow[t]{2}{*}{ Denpasar } & $\mathrm{N}$ & 2 & 4 & 1 & 10 & 17 \\
\hline & $(\%)$ & 11.80 & 23.50 & 5.90 & 58.80 & 100 \\
\hline \multirow[t]{2}{*}{ Total } & $\mathrm{N}$ & 28 & 22 & 10 & 13 & 73 \\
\hline & $(\%)$ & 38.36 & 28.77 & 15.07 & 17.81 & 100 \\
\hline
\end{tabular}

Table 4. Total of canonical structure of body measurements of Bali civet

\begin{tabular}{lll}
\hline Body measurements & CAN1 & CAN2 \\
\hline Bodyweight & -1.94 & -0.46 \\
Body length & $\mathbf{0 . 7 6}$ & -0.93 \\
Total animal length & -0.61 & 0.11 \\
Body height & 0.75 & $\mathbf{0 . 9 6}$ \\
Head length & -0.20 & -0.50 \\
Head width & -0.14 & $\mathbf{0 . 9 4}$ \\
Chest circumference & 0.06 & -1.28 \\
Inner chest width & 0.62 & 0.48 \\
Front leg length & 0.26 & -1.45 \\
Hind leg length & -1.03 & 0.79 \\
Tail length & $\mathbf{1 . 0 4}$ & 0.53 \\
Tail base length & 0.38 & 0.80 \\
Tail end length & 0.17 & 0.32 \\
\hline
\end{tabular}

Table 5. The genetic distance matrix of Bali civet from four areas

\begin{tabular}{|c|c|c|c|c|}
\hline \multirow{2}{*}{ Population } & \multicolumn{4}{|c|}{ Population } \\
\hline & Bangli & Tabanan & Gianyar & Denpasar \\
\hline Bangli & 0.00 & - & - & - \\
\hline Tabanan & 34.28 & - & & \\
\hline Gianyar & 41.93 & 12.04 & - & \\
\hline Denpasar & 36.40 & 7.26 & 10.53 & - \\
\hline
\end{tabular}

The scattering of Bali civets in each population according to the morphometry measurements based on the canonical discriminant quadrant is shown in Figure 3. The Bali civets from Bangli have separated the group from the other quadrants. They were located at quadrant II and IV and only had a slight intersection part with Bali civets from other populations. It means that Bali civets from Bangli region have a particular difference of morphometry measurement than the other regions. The instance is the front leg size. This was also illustrated that Bangli has a bit different genetic than other regions. Canonical Discriminant Analysis (CDA) can be used to measure the relationship between categorical variables, namely groups of variables belonging to individuals or populations, and a set of independent variables (Zhao and Maclean 2000).

\section{The genetic distance and phylogenetic relationship of Bali civet}

Table 5 showed that Bali civets from Bangli area have a further genetic distance than other regions with values ranging from 34.28 to 41.93 . This may be caused by the Bangli region located in the mountainous area, far away from other populations. This may impede the free movement of those civets into other populations. While, the closest genetic distance was between Tabanan and Denpasar population with value 7.26. This is presumably caused by the closest location among those two places allowing civets to move back and forth between the two locations. Based on local farmers' information, Denpasar civets came from Tabanan through trading activities.

Based on the matrix of genetic distance, we constructed the phylogenetic tree, as showed at Figure 4. This illustrates Bali civets from four different locations are grouped into three clusters. The first cluster is from Tabanan and Gianyar populations, the second one comes from Tabanan, Denpasar and Gianyar populations, and the last one is Bangli civets. It is clearly displayed that Tabanan civets have the closest genetic relation to Denpasar ones. Those two locations are also closer to Gianyar, while Bangli civet population was separated from them.

The dendrogram generated from the genetic distance matrix, so it can also elaborate on the genetic distance among the populations. Hence, the implementation of morphometric characters in this investigation can determine the genetic distance and phylogenetic relationship among Bali civets.

In conclusion, the presence of morphometric diversity on Bali civets from four different regions of Bali island can be adjusted through the variations of quality characters such as hair color consisting of four colors (i.e., grayishbrown; black; brownish-yellow; and white). Also, it can be found through the variation of quantitative characters obtained from the variation of morphological measurements obtained from the value of morphometric similarity, canonical discriminant analysis, the genetic distance matrix, and the phylogenetic relationship. However, the strong variables differentiator of morphometric measurements that can control the Bali civet genetic variations were body length, body height, head 
width, and tail length. This means that if these variables are changed, then the morphometric character of the animal will change too. Hence, the strength of the finding in this study is a molecular approach is needed to support the scientific argument.

\section{ACKNOWLEDGEMENTS}

This research was conducted through the International Collaboration Research scheme between University of Muhammadiyah Malang, Indonesia and University of Murcia, Spain funded by the Indonesian Government through the Directorate General of Higher Education, Ministry of Research, Technology and Higher Education and University of Muhammadiyah Malang in 2018 by contract No.: E.5.c/064/DPPM-UMM/L/III/2018. The authors are grateful to Rector of the University of Muhammadiyah Malang providing the opportunity for us to carry out this research. Also to Dwi Prasetyo, Rukmini and Sri Wahyuni for their assistance during sampling in the field and in the laboratory.

\section{REFERENCES}

Apriliani F. 2012. Morfologi Organ Reproduksi Betina Musang (Paradoxurus hermaphroditus). [Hon. Thesis]. Institut Pertanian Bogor (IPB), Bogor. [Indonesian]

Bale R. 2019. Wildlife Watch: The Disturbing Secret Behind the World's Most Expensive Coffee. National Geographic. https://www.nationalgeographic.com/news/2016/04/160429-kopiluwak-captive-civet-coffee-Indonesia/. [15 December 2019].

Cardillo M, Mace GM, Jones KE, Bielby J, Bininda-Emonds ORP, Sechrest W, Orme CDL, Purvis A. 2005. Multiple causes of high extinction risk in large mammal species. Science 309: 239-241.

Castle WE. 1954. Coat color inheritance in horses and in other mammals. Genetics 39: 35-44.

Dev Choudhury KB, Anil D, Munmun S, Jiten R. 2015. Phenotypic morphometric study on an adult Common Palm Civet (Paradoxurus hermaphrodites). IOSR J Agric Vet Sci (IOSR-JAVS) 8 (4.1): 37-38.

Dossa LH, Wollny C, Gauly M. 2007. Spatial variation in goat population from Benin as revealed by multivariate analysis of morphological traits. Small Rum Res 73:150-159.

Duckworth JW, Timmins RJ, Choudhury A, Chutipong W, Willcox DHA, Mudappa D, Rahman H, Widmann P, Wilting A, Xu W. 2016 Paradoxurus hermaphroditus. The IUCN Red List of Threatened Species: e.T41693A45217835. DOI: 10.2305/IUCN.UK.20161.RLTS.T41693A45217835.en. [Accessed on 12 March 2018].

Eaton JA, Wust R, Wirth R, Shepherd CR, Semiadi, G, Hall J, Duckworth JW. 2010. Recent records of the Javan Small-Toothed Palm Civet Arctogalidia (trivirgata) trilineata. Small Carnivore Conserv 43:1622.

Herera M, Rodero E, Gutierrez MJ, Pena F, Rodero JM. 1996. Application of multifactorial discriminant analysis in the morphostructural differentiation of Andalusian caprine breeds. Small Rum Res 22: 3947.

Ilham F. 2012. Keragaman Fenotip Kambing Lokal Kabupaten Bone Bolango. Laporan Penelitian Dasar Keilmuan, Universitas Negeri Gorontalo, Gorontalo. [Indonesian]

Jennings AP, Veron G. 2009. Family Viverridae (civets, genets, and oyans). In: Wilson DE, Mittermeier RA (eds.). Handbook of the mammals of the world. Vol. 1. Carnivores. Lynx Edicions, Barcelona, Spain.

Jothish PS. 2011. Diet of the Common Palm Civet Paradoxurus hermaphroditus in a rural habitat in Kerala, India, and its possible role in seed dispersal. Small Carnivore Conserv 45: 14-17.

Kemper KE, Visscher PM, Goddard ME. 2012. Genetic architecture of body size in mammals. Genome Biol 13 (4): 244
Kosim I. 2015. Gambaran Anatomi dan Histologi Lidah Musang (Paradoxurus hermaphroditus). [Hon. Thesis]. Institut Pertanian Bogor (IPB), Bogor. [Indonesian]

Laela A. 2013. Pengelolaan Kesejahteraan Musang dan Pemanfaatannya Sebagai Satwa Peraga di Taman Margasatwa Ragunan. [Hon. Thesis]. Institut Pertanian Bogor (IPB), Bogor. [Indonesian]

Meiri S, Dayan T, Simberloff D, Grenyer R. 2009. Life on the edge: carnivore body size variation is all over the place. Proc Biol Sci 276 (1661): 1469-1476.

Mudappa D, Kumar A, Chellam R. 2010. Diet and fruit choice of the Brown Palm Civet Paradoxurus jerdoni, a Viverrid endemic to the Western Ghats Rainforest, India. Trop Consv Sci 3: 282-300.

Nakabayashi M, Ahmad AH, Kohshima S. 2016. Behavioral feeding strategy of frugivorous civets in a Bornean rainforest. J Mammal 97 (3): 798-805.

Nakashima Y, Sukor JA. 2010. Importance of common palm civets (Paradoxurus hermaphroditus) as a long-distance disperser for largeseeded plants in degraded forests. Tropics 18: 221-229.

Nakashima Y, Nakabayashi M, Sukor JA. 2013. Space use, habitat selection, and day-beds of the common palm civet (Paradoxurus hermaphroditus) in human-modified habitats in Sabah, Borneo. J Mammal 94 (5): 1169-1178.

Nijman V, Spaan D, Rode-Margono EJ, Roberts PD, Wirdateti, Nekaris KAI. 2014. Trade in Common Palm Civet Paradoxurus hermaphroditus in Javan and Balinese markets, Indonesia. Small Carnivore Conserv 51: 11-17.

Nei M. 1987. Molecular Evolutionary Genetics. Columbia University Press. New York.

Nur NK. 2013. Manajemen Penangkaran dan Aktifitas Harian Musang di Penangkaran CV Kopi Luwak Indonesia Pengalengan Bandung. [Hon Thesis]. Institut Pertanian Bogor (IPB), Bogor. [Indonesian]

Pai M. 2008. Common Palm Civet (Pardoxurus hermaprodhitus), The Vanishing Species 39

Patou ML, Wilting A, Gaubert P, Jacob A, Cruaud C, Jenning AP. 2010. Evolutionary History of the Paradoxurus Palm Civets - a New Model for Asian biogeography. J Biogeogr 37: 2077-2097.

Pissard A, Arbizu C, Ghislain M, Faux A, Paulet S, Bertin P. 2008. Congruence between morphological and molecular markers inferred from the analysis of the intra-morphotype genetic diversity and the spatial structure of Oxalis tuberosa. Mol Genet 132: 71-85.

Pocock RI. 1939. The fauna of British India, including Ceylon and Burma. Mammalia. Vol. 1. Taylor and Francis, London.

Putra SM. 2012. Morfologi Organ Reproduksi Musang Luak Jantan (Paradoxurus hermaphroditus). [Hon. Thesis]. Institut Pertanian Bogor (IPB), Bogor. [Indonesian]

Rizkiantino R. 2015. Studi Morfologi Usus Musang (Paradoxurus hermaphroditus). [Hon. Thesis]. Institut Pertanian Bogor (IPB), Bogor. [Indonesia].

Sharma SK. 2004. Occurrence of albino common palm civet and northern palm squirrel in Southern Rajasthan. Zoos' Print J 19 (5): 1483.

Steel RGD, Torrie JH. 1995. Prinsip dan Prosedur Statistika. Terjemahan: Bambang Sumantri. Gramedia Pusaka Utama, Jakarta. [Indonesian]

Su S, Sale J. 2007. Niche differentiation between Common Palm Civet Paradoxurus hermaphroditus and Small Indian Civet Viverricula Indica in regenerating degraded forest, Myanmar. Small Carnivore Conserv 36: 30-34.

Sun Y, Liu Y, Sun X, Lin Y, Yin D, Xu S, Yang G. 2019. Insights into body size variation in cetaceans from the evolution of body-sizerelated genes. BMC Evol Biol 19: 157. DOI: 10.1186/s12862-019$1461-9$.

Suwed MA, Napitupulu R. 2011. Panduan Lengkap Kucing. Penebar Swadaya. Depok. [Indonesian]

Fabriciusová V, Kaňuch P, Krištín A. 2008. Body size patterns of Pholidoptera frivaldskyi (Orthoptera) in very isolated populations. J Orthoptera Res 17 (2): 171-176.

Warwick EJ, Astuti JM, Hardjosubroto W. 1995. Pemuliaan Ternak. Gadjah Mada University Press, Yogyakarta. [Indonesian]

Widayati MW. 2003. Studi Sifat Kualitatif dan Kuantitatif Kuskus di Pulau Moor Distrik Napan Kabupaten Nabire. [Hon. Thesis]. Universitas Negeri Papua, Manokwari. [Indonesian]

Wilson DE, Reeder DM. 2005. Mammal Species of the World: a Taxonomic and Geographic Reference. John Hopkins University, Baltimore, MD

Wozencraft WC. 2005. Order Carnivora. In: Wilson DE, Reeder DM (eds.). Mammal Species of the World: A Taxonomic and Geographic Reference. 3rd ed. Johns Hopkins University Press, Baltimore, MD. 
Wright M, Walters S. 1981. The Book of the Cat. Summit Books, New York.

Zelditch ML, Swiderski DL, Sheets HD, Fink WL. 2004. Geometric Morphometrics for Biologists: A primer. Academic Press, New York.
Zhao GA, Maclean AL. 2000. Comparison of canonical discriminant analysis and principal component analysis for spectral transformation. Photogramm Eng Remote Sens 6 (7): 841-847. 